\title{
Innovation Propensity in Croatian Enterprises: Results of a Community Innovation Survey
}

\author{
Zoran Aralica, Domagoj Račić, Dubravko Radić*
}

\section{Abstract}

This paper assesses the determinants of innovation activities in Croatian enterprises and their implications for innovation policy. A Type-2 Tobit model is used for modelling the innovation behaviour of Croatian companies, based on the results of a Community Innovation Survey conducted for the period 2001-2003. This model identified the positive effects of conditions for enterprise growth (enterprise size and demand pull variable) and the integration of enterprises into international flows of capital and goods (through foreign direct investments) as well as R\&D activities. These variables can be tackled through a more effective policy framework that should increase competitiveness within industries in order to stimulate the demand for innovation. The focus should be on fostering enterprise growth, attraction of FDI with strong spillover effects, and stimulating the export capability of enterprises. Only in such a context can the positive effects of engagement in R\&D be maximised.

Key words: Innovation activities, Community Innovation Survey, Croatia

JEL: 031

DOI: 10.2478/v10033-008-0008-6

\section{Introduction}

Innovation tends to be considered a major driver of both economic growth and the competitiveness of companies and industries. However, measurement and analysis of innovative activities and their impacts at the micro-, meso-, and macro-levels have often been burdened with conceptual and applicative difficulties. Following the Oslo Manual (cf. OECD 1997), a methodology for collecting and interpreting enterpriselevel data on technologicaland organisationalinnovation has been developed and applied to the countries of the European Union and its new member states. In addition to economic imperatives, the transition economies of Central and Eastern Europe have tended to embrace innovation-related issues within their accession into the European Union, which defines the development of

* The authors would like to thank Slavo Radošević, Krešimir Žigić and Vladimir Cvijanović for valuable comments. a knowledge-based economy as a crucial policy goal (CEU 2000).

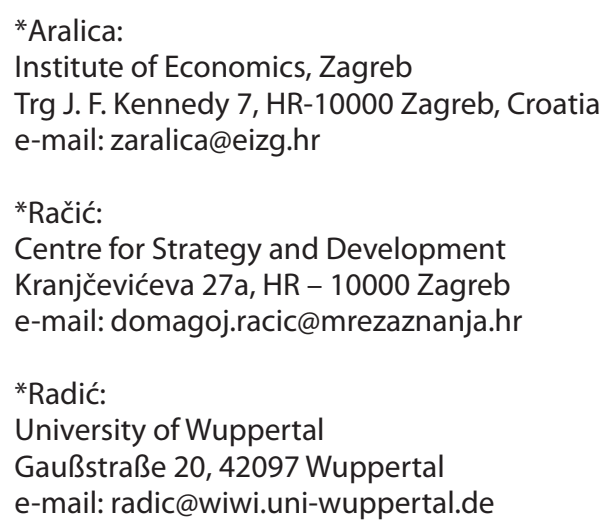

Centre for Strategy and Development Kranjčevićeva 27a, HR - 10000 Zagreb e-mail: domagoj.racic@mrezaznanja.hr

*Radić:

University of Wuppertal

Gaußstraße 20, 42097 Wuppertal

e-mail: radic@wiwi.uni-wuppertal.de 
The existing research into innovation (cf. Božić and Radas 2005; Račić et al. 2005), innovation policy (cf. Andrijević-Matovac 2003; Aralica and Bačić 2005; Švarc 2006) and competitiveness (cf. NCC 2006) indicates the inadequate innovation performance of the Croatian economy and deficiencies in the processes supporting the development and commercialisation of new knowledge. However, these findings have not so far been supported by a comprehensive firm-level innovation survey.

The aim of the paper is to explore the determinants of innovation propensity in Croatia, which should help elucidate some of the key factors of the economic transformation required to fulfil the requirements of its expected EU accession and advancement of the Lisbon agenda in general. The paper aims to address the absence of a firm-level survey and transcend descriptive analysis by econometric modelling, providing a useful input into the formulation of a more effective innovation policy. This analysis of innovation activities is based on the first Community Innovation Survey (CIS) conducted in Croatia for the years 2001 2003.

The rest of the paper is organized as follows: We start with a brief literature review of the determinants of innovation activities. Section three introduces the dataset and offers some descriptive results that will form the basis for the econometric modelling. In section four, we will estimate a Tobit model which explicitly takes the peculiarities of CIS type data into account. Most of the variables that might explain the innovation behaviour of firms are available for innovative firms, but not for their non-innovative counterparts. A Tobit model addresses this data problem by assuming a two step model for innovations. In the first phase, the decision of the firm to introduce a new product/ service is modelled. Given a positive decision at the first step, the share of innovative sales is measured in a second phase using a simple regression model. The final section consists of concluding remarks..

\section{Literature Review}

The influence of innovation activities on firm performance has been widely acknowledged (Griffith et al. 2006). Innovation activities affect firm performance in terms of value added, sales, employment and profitability (cf. Lööf and Heshmati (2006), Crepon, Duguet, and Mairesse (1988)).

However, when it comes to innovation activity determinants, there is a much greater diversity of views and approaches. The results of various studies demonstrate that innovation is a complex phenomenon influenced by a large number of factors (cf. Crespi 2004, p. 21). Given the variety of potential causal relationships within which innovation activities can be placed, the literature dealing with innovation activity determinants is extremely extensive. It links innovation with diverse topics and places it within different contexts. Empirical evidence about innovation activities determinants has been flourishing in the last twenty years and has shown a variety of results in different national contexts (cf. a broad literature survey by Cohen (2005).

Given the variety of the possible explanatory variables used in the literature, empirical analysis inevitably needs to focus on the variables that are deemed more relevant and/or the variables for which reliable data are available. Since this paper is based on Community Innovation Survey firm-level data, it deals with the characteristics of innovation activities and connects innovation and other firm activities (cf. Dosi 1988), pointing to the context and/or content of innovation-related processes.

Firm specific capabilities have become important recently in the analysis of firm innovation activity determinants and their relation to firm performance (cf. Cohen 2005, p. 201). The focus of this analysis has been on research and development (R\&D) activities and their relation to innovation activities. Various qualitative analyses show the importance of R\&Drelated capabilities for the process and commercial outcomes of a firm's innovative activities (Teece 1986, 1977; Mowery and Rosenberg 1989). An important issue is whether innovation activities are based on and related to $R \& D$. R\&D activity is an indispensable part of more complex innovation activities with longer-term effects on companies and markets, but innovation is by no means restricted to R\&D. A significant amount of innovation and improvements originates from design improvements, 'learning by doing' and 'learning by using' (Arrow 1962; Rosenberg 1982; Mowery and Rosenberg 1989) and such informal efforts are generally embodied in people and organisations (Teece 1977, 1986; Pavitt 1986). In the analysis of innovation patterns in Central and Eastern European countries (CEEC), Radosevic (1999) found that the companies from CEECs purchase relatively more embodied technology than companies from the EU; they also have a lower share of R\&D expenditures in total innovation expenditures. Non-R\&D sources of innovation also mean that the forms of protection of innovation are diverse and include formal (patents, copyright and trade marks) and informal (e.g. design complexity, trade secrets, faster market entry) means (cf. Crespi 2004). Cohen, Nelson and Walsh (2000) found that the other ways of protecting intellectual property - such as being first in the market, using trade secrets and developing complex designs - are more effective 
than patents. Baldwin, Hanel, and Sabourin (2000) found that the causal relationship is much stronger going from innovation to the decision to use patents than from the use of patents to innovation. However, innovation incentives are not entirely exogenous, as innovation capability further stimulates companies to protect their innovation results by patents.

High risks and costs and the lack of available knowledge induce firms to seek external partners, thereby developing innovations in collaboration with suppliers, customers, competitors and academic institutions. The importance of cooperation has risen steadily alongside the complexity, risk and cost of innovation activities. Innovation cooperation influences innovation activities through the pattern of collaborative relationships and partner type involved (Vinding 2002). This relationship is mutually reinforcing - external linkages facilitate innovation, and at the same time innovative outputs attract further collaborative ties (Powell and Grodal 2005, p. 67-68).

Competition increases the interaction and dynamism of market processes; consequently, it usually facilitates demand for innovative products and/or services. The competitiveness and innovation activities are primarily linked via the national innovation capacity, which involves R\&D supply, absorption capacity, the diffusion of knowledge and market demand (cf. Radošević, 2004). However, in a particular industry, competition incurs specific innovative expenditures on firms; for example, in high-tech industry it leads to the internalization of innovative activities, where the majority of innovative products are a result of firms' own R\&D investments (cf. Baumol 2004).

An educated workforce tends to be a prerequisite for undertaking innovation. The presence of employees engaged in R\&D activities can facilitate successful innovation activities. More specifically, the number of employees engaged in $R \& D$ favours the generation of innovations; this effect increases with the special skills of the personnel charged with these activities (cf. Leiponen 2005).

The recent stream of literature exploring innovation activities within SMEs has been growing. SMEs' innovativeness is the result of various factors, such as industry-specific factors, firm-specific factors and innovation-specific factors (cf. Hausman 2005). Within SMEs it seems that the capability of entrepreneurial behaviour is the crucial factor behind innovation activities (e.g. Caird 1994, Lipparini and Sobrero 1994, Kickul and Gundry 2002).

In the last twenty years, innovation has become closely linked to the internationalisation of business activities. Two groups of literature have appeared that examine the determinants of innovation activities in international business activities. The first group examines the distinction between foreign and domestic ownership with regard to innovation performance. A standard argument in this context is that increasing FDI also increases the inflow of external knowledge and technology. Račić et al. (2005) found that foreignowned firms were more innovative than domestic firms and that this relation was affected by the characteristics of foreign direct investment in Croatia. However, Jaklič, Rojec, and Damijan (2006) found that innovation cooperation influences innovation activities for the domestic partner only (and not for the international ones) and claimed that foreign ownership was not in fact a significant determinant of innovation activity. The second stream of literature analyses the impact of multinational enterprises (MNE) and their subsidiaries created through FDI on internationalisation of innovation activities. The results of empirical studies confirm that multinational companies have a positive influence on local subsidiaries and their innovation activities through knowledge transfer (e.g. Aitken and Harrison 1999, Girma, Greenaway, and Wakelin 2001, Damijan et. al. 2003). It seems that the relation between parent companies and subsidiary is a major challenge for MNEs, specifically the issue of devising an organisational system capable of transferring know-how across units and locations, and allowing locally generated know-how to be used throughout the multinational organisation (Sanna-Randaccio and Veugelers 2003).

\section{Dataset and Descriptive Results}

In this section the dataset is briefly introduced and some descriptive results are presented. The data have been obtained through the first firm-level innovation survey in Croatia, in which data was collected in accordance with the Oslo Manual (cf. OECD, 1997). The survey covers the period from 2001 to 2003. This postal survey was commissioned by the Ministry of Science, Education and Sports. It was undertaken in autumn 2004 by the Institute of Economics. The available literature on the implementation of CIS III was also consulted (e.g. Kurik et al., 2002; Boia et al., 2003). In addition to general information about the enterprise, the survey covered the following aspects of innovation activities: product and process innovation, expenditures on innovation activities, intramural research and experimental development, innovation cooperation, sources for innovation, factors hampering innovation activities, innovation protection, and important strategic and organisational changes in the enterprises. The survey was based on a stratified representative sample of all Croatian enterprises in relevant manufacturing and service sectors. The sample consists of 1272 firms. The following table 


\begin{tabular}{lcccc}
$\begin{array}{c}\text { Number of } \\
\text { employees }\end{array}$ & Number of firms & Share of firms & $\begin{array}{c}\text { Share of firms } \\
\text { with product } \\
\text { innovation }\end{array}$ & $\begin{array}{c}\text { Share of firms } \\
\text { with process } \\
\text { innovation }\end{array}$ \\
\hline 10 & 540 & 0.42 & 0.27 & 0.19 \\
{$[10-50)$} & 253 & 0.20 & 0.32 & 0.28 \\
{$[50-250)$} & 145 & 0.11 & 0.37 & 0.27 \\
$\geq 250$ & 334 & 0.26 & 0.12 & 0.10
\end{tabular}

Table 1:

Size, distribution and innovation propensity of Croatian firms ${ }^{12}$

shows the distribution of the firms according to the number of employees.

There seems to be an inverted U-shape relation between the size of the firms and their innovation propensity. The share of micro firms with less than 10 employees that have introduced product or process innovations amounts to $27 \%$ and $19 \%$, respectively. These shares increase with firm size. Consequently, firms with 50-250 employees are the most innovative ones regarding product innovations (37\%). However, in the case of firms with more than 250 employees, the share of firms with product innovations drops again markedly to $12 \%$. The low innovativeness of the largest enterprise may reflect temporary restructuring difficulties at several large enterprises, rather than a systemic feature of the economy. The relation between firm size and process innovations varies less, but, again, drops in the case of the largest enterprises.

The following table shows the industrial affiliation of Croatian firms. Columns two and three contain the share of innovative firms in the different industry sectors. We have considered two different innovation indicators, namely product and process innovations.

\begin{tabular}{|lccc|}
\hline Industry Sector & Share of firms & $\begin{array}{c}\text { Share of firms with } \\
\text { product Innovation }\end{array}$ & $\begin{array}{c}\text { Share of firms with } \\
\text { process innovation }\end{array}$ \\
\hline Mining & 0.01 & 0.13 & 0.25 \\
Food & 0.06 & 0.47 & 0.36 \\
Textile & 0.07 & 0.22 & 0.16 \\
Wood & 0.09 & 0.27 & 0.19 \\
Chemicals & 0.03 & 0.39 & 0.23 \\
Plastic & 0.04 & 0.36 & 0.38 \\
Glass & 0.04 & 0.34 & 0.31 \\
Metals & 0.06 & 0.34 & 0.34 \\
Machinery & 0.04 & 0.51 & 0.28 \\
Electrical equipment & 0.10 & 0.34 & 0.28 \\
Vehicle & 0.02 & 0.33 & 0.17 \\
NEC & 0.05 & 0.28 & 0.24 \\
Wholesale trade & 0.06 & 0.04 & 0.11 \\
Retail & 0.12 & 0.10 & 0.08 \\
Transport & 0.08 & 0.16 & 0.12 \\
Finance & 0.05 & 0.19 & 0.15 \\
Other services & 0.10 & 0.38 & 0.20 \\
\hline
\end{tabular}

Table 2:

Industrial affiliation and innovation propensity of Croatian firms 
The figures in Table 2 reveal that the machinery (0.51) and food industries (0.47) contain the highest share of firms that have introduced new products, whereas the plastic (0.38) and food industries (0.36) lead when it comes to the introduction of process innovations. Moreover, there is no clear relationship between the level of complexity of products and technologies of particular industries and their level of innovativeness. That could be due to the role of other factors at the micro level that may influence innovation processes such as product diversification, firmspecific capabilities ${ }^{1}$ as well as the level of competition in a given industry ${ }^{2}$.

\section{Econometric Modelling}

In the following section we will model the innovation behaviour of Croatian firms using a Type-2 Tobit model. Such a procedure has become common for CIS-type data since most of the variables that might explain the innovation behaviour of firms are only available for innovative firms but not for their non-innovative parts (cf. Raymond et al. 2006). As has been noted by Mohnen and Dagenais, (2000, p. 10), 'there is little information in the CIS dataset regarding non-innovators'. We thus have very little information in the CIS database to discriminate between innovators and non-innovators. As a consequence, only a censored regression approach can be estimated which explicitly takes account of this data structure, as will be explained in more detail below.

Regarding possible dependent variables, the CIS dataset contains a number of indicators that can be classified into input and output side oriented variables. Input oriented indicators of innovation activities included in the questionnaire are $R \& D$ expenditures and variables indicating whether firms are engaged in R\&D co-operation or not. Although widely used, indicators based on R\&D bear several limitations as a measure of technological change. First, they underestimate technological activities in manufacturing and service industries where much of the technical change takes place around design and manufacturing that is not captured by the concept of R\&D (Patel and Pavitt, 2005, p.21). Second, small and medium sized firms often do not possess a separate business unit devoted to R\&D. Using R\&D expenditure or $R \& D$ personnel as a measure will therefore underestimate their innovation activities. Finally, as an input measure, $R \& D$ expenditures are only loosely connected with the output of technological change.

On the output side, the CIS questionnaire contains information on patents granted to firms, which are another frequently used measure of technological activity. However, several drawbacks have to be taken into account when considering patents as a measure of technological change. First, not every innovation is based on a patentable invention, and not every patent results in a marketable product. Second, in certain industries - like the automotive industry - patents play only a minor role as a barrier to imitation and hence differences in patent activities across industries will not always reflect differences in innovation activities. Third, institutional, legal and economic factors related to the process of obtaining a patent will also have an impact on patent intensities (for a discussion on patents, cf. Griliches 1990). Finally, simply looking at patents says nothing about the economic value of the innovation (cf. Patel and Pavitt 2005).

We therefore decided to use an output-oriented measure, namely the declaration of whether a firm has introduced a new product/service and the percentage of sales due to this new product/service. ${ }^{3}$ The advantage of such an approach is the ability to directly measure the economic outcomes of innovation activities. There are, however, also some disadvantages that should be mentioned. Although the questionnaire contains a detailed description of the notion of a new product/service, CIS surveys reflect the subjective view of firms, which have to decide what they regard as a product/service innovation. This is especially pronounced in the first applications of such surveys in a new environment. ${ }^{4}$

A Type-2 Tobit model consists of two steps. In the first step, the decision of a firm to introduce a new product/ service is modelled using a simple Probit model. Given a positive decision at the first stage, the share of innovative sales, $y_{i}$, follows a simple censored regression model at the second stage. Formally: ${ }^{5}$

$$
y_{i}=\left\{\begin{array}{l}
0, \text { iff } y_{i}^{*}=x_{i}^{\prime} \beta+\varepsilon_{i}<0 \\
z_{i}^{\prime} \gamma+v_{i}, \text { iff } y_{i}^{*}=x_{i}^{\prime} \beta+\varepsilon_{i} \geq 0
\end{array}\right.
$$

The latent variable, $y_{i}^{*}$ can be interpreted as the propensity to innovate. ${ }^{6}$ In the first stage we use data on innovators and non-innovators: If $\mathrm{y}^{*}$, exceeds the threshold level, which is set to zero for identification, the firm decides to innovate. If, on the other hand, $y^{*}$ is below zero, the firm decides not to innovate and what we observe in the dataset is thus $y_{i}=0$. In the second step innovative sales as measured by $y_{i}$ are modelled by the regression part of the Tobit model. It should be noted that for a type-2 Tobit model the first stage decision whether to be innovative or not depends on a set of explanatory variables $x$, whereas the decision about the amount of innovative sales is assumed to depend on another set of exogenous variables $z$. The set of these variables may not be identical. We further assume that the two error terms $\varepsilon$ and $v$ follow a standard normal distribution. 
As already stated, due to the construction of the CIS questionnaire, the set of variables for the first stage decision is rather limited. We considered the following:

- Size dummies: establishments with 11-50 employees, establishments with 51-250 employees and establishments with more than 250 employees.

- 16 industry sector dummies.

Size is a traditional explanation for innovative behaviour. ${ }^{8}$ Larger firms have better access to capital markets or more internal funds to finance uncertain and risky innovation projects. They have better access to competent and specialised staff, which can foster the development of specific competences. R\&D activities exhibit economies of scale and scope, i.e. larger firms have better opportunities to diversify the risks associated with innovation activities. Fixed costs associated with R\&D investments can be distributed over a larger volume of sales. Finally, there might be complementarities between innovation and certain activities, e.g. marketing or planning, which are more pronounced among larger firms. There are, however, also counteracting effects. Larger firms tend to be more bureaucratic and hierarchical, which can hinder innovation activities. Also associated with an increasing size is a loss of managerial control of innovation activities. Hence, the impact of firm size on innovations is not clear-cut. For transition economies another point becomes important in this context. During the transition period in Croatia a lot of formerly state-owned enterprises were reduced through restructuring or split up into smaller units (cf. Račić and Cvijanović 2005) Moreover, new small and medium sized companies were founded, but their innovation capability tends to be limited.

Due to missing data, industrial affiliation has to measure a set of different effects. First of all, different industries are characterized by different technological conditions and opportunities. Examples include the maturity of the technology used, the rate of technological advance, and the 'closeness' to science and externally generated knowledge through R\&D co-operation. If internal 'absorptive' capabilities are available, as measured, for example, by the number of $R \& D$ personnel, such external technological opportunities can be exploited for innovations. Including industry dummies will also control for market characteristics in such industries, e.g. market concentration and differing demand conditions.

For the second stage, i.e. the amount of innovative sales, the following variables were included in the regression:

- Size of the firm measured by the following dummies: establishments with 11-50 employees, establishments with 51-250 employees and establishments with more than 250 employees.

- Share of employees with a university degree

- Share of capital foreign investors hold

- Dummy variable indicating whether the international market is the most important

- Dummy variable indicating whether the firm is continuously engaging in $R \& D$ or not

- Dummy variable indicating R\&D cooperation with other firms or institutions such as universities

- Demand pull indicator, which equals one if the aim of the product innovation was to extend the product range or to open up new markets. ${ }^{9}$

The economic reasons for the inclusion of the size variable are the same as those for the first step. However, firms differ also in their specific technology capabilities. These capabilities are reflected in differences in the qualification structure of the employees, in the internal organization of $R \& D$, manufacturing and marketing and the ways of information processing. Firms with better in-house R\&D capabilities will more successfully pursue innovations and also have better absorptive capacities to gain from outside technological opportunities. Therefore we also include the share of highly qualified employees, i.e. employees with a university degree, and continuous engagement in R\&D as a proxy for the internal technological capabilities of a firm.

Better in-house technology capabilities are especially necessary when cooperating with other institutions in R\&D since these firms have better absorptive capacities to gain from such outside technological opportunities. We therefore also include a corresponding dummy variable which equals one if a firm engages in such R\&D cooperation.

Since firms' innovation activities respond to economic incentives, especially to changing demand conditions, large and fast growing markets will increase the return on investment in innovations. We control for this by including a demand pull indicator which equals one if the aim of the product innovation was to extend the product range or to open up new markets. Another factor that might spur innovation activities is competition. Therefore, it might be expected that internationally oriented firms are the more innovative ones.

The estimation of the Tobit model was done using a simple two-step procedure. In the first step the parameters for the Probit model were obtained. Given these parameters, a Mills ratio, $\varphi\left(x_{i}^{\prime} \beta\right) / \Phi\left(x_{i}^{\prime} \beta\right)$, was calculated and plugged into the second stage regression conditional on positive shares of innovative sales. ${ }^{10}$

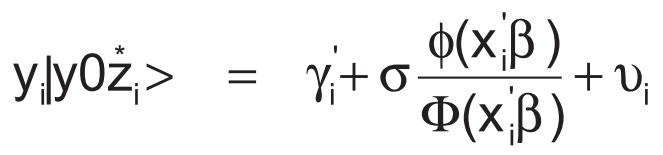

where $\varphi($.$) is the standard normal density and \Phi($.$) the$ standard normal cumulative density function. 


\begin{tabular}{|c|c|c|c|c|}
\hline & Parameter & SE & t-Value & p-Value \\
\hline Constant & -0.75 & 0.08 & -9.34 & 0.00 \\
\hline No. of employees [10 - 50] & 0.18 & 0.11 & 1.68 & 0.09 \\
\hline No. of employees [50 - 250) & 0.31 & 0.13 & 2.38 & 0.02 \\
\hline No. of employees $\geq 250$ & -0.64 & 0.11 & -5.61 & 0.00 \\
\hline MFX employees [10 - 50) & 0.05 & 0.03 & 1.62 & 0.11 \\
\hline MFX employees [50- 250) & 0.10 & 0.05 & 2.22 & 0.03 \\
\hline MFX employees $\geq \mathbf{2 5 0}$ & -0.17 & 0.03 & -6.64 & 0.00 \\
\hline & \multicolumn{2}{|c|}{$x^{2}$-value } & \multicolumn{2}{|c|}{ p-Value } \\
\hline Industry dummies & \multicolumn{2}{|c|}{159.88} & \multicolumn{2}{|c|}{0.00} \\
\hline Overall & \multicolumn{2}{|c|}{143.10} & \multicolumn{2}{|c|}{0.00} \\
\hline Number of observations & \multicolumn{4}{|c|}{992} \\
\hline Pseudo $R^{2}$ & \multicolumn{4}{|c|}{0.10} \\
\hline
\end{tabular}

Table 3:

Probit regression results: Product innovation yes/no

The figures in Table 3 refer to the Probit equation, i.e. the decision whether to introduce an innovation or not, and indicate that - according to the previous reasoning - the number of employees has an inverted U-shape impact on the marginal likelihood of introducing a new product or service. ${ }_{11}$ Compared to micro-establishments with less than 10 employees, establishments with 11-50 employees have a $5 \%$-points higher probability to introduce an innovation. Establishments with 51-250 employees have an ever higher probability (by 10\%-points), whereas large companies have a lower innovation probability than microestablishments (by 17\%-points).

Now we turn to the estimation results for the censored regression equation. Contrary to the previous inverted U-shape results, the size of firms now has a negative marginal impact on the share of innovative sales (Table 4). Or to put it simply: size has an inverted U-shape effect on

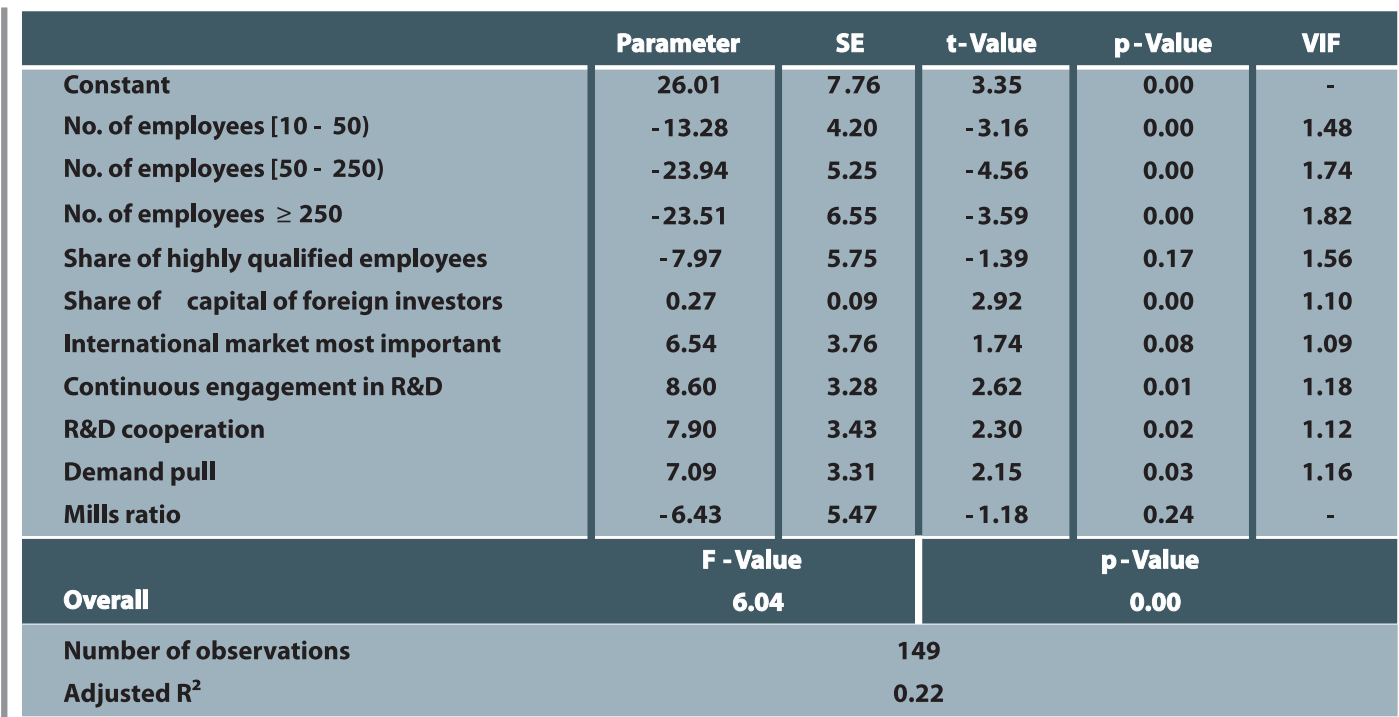

Table 4:

Censored regression results:

Share of positive innovative sales 
the marginal probability to introduce an innovation, i.e. micro establishments (less than 10 employees) and large establishments are less innovative than SMEs. On the other hand, the impact on innovative sales is larger for smaller firms.

Except for the qualification structure of firms, which turns out to be insignificant, all other variables have the a-priori expected sign. Continuous engagement in $R \& D$ and $R \& D$ cooperation, turn out to be positive and significant. Since $R \& D$ activities have been recognised as a crucial factor of innovation activity and/or innovation capacity (Cohen and Levinthal, 1989) this result is not surprising, despite the fact that overall R\&D expenditures of analysed firms tend to be relatively low (cf. Račić et al., 2005). Increasing the participation of foreign investors by $1 \%$ of the capital they hold increases innovative sales by $0.27 \%$. Demand pull is statistically significant at the $8-\%$ level, indicating that the share of innovative sales is higher if the innovation aims at extending the product range. On the other hand, the insignificance of employee education levels seems to indicate the low capability of companies to upgrade and utilise the acquired knowledge of their employees in order to develop and launch new economically viable products.

The statistical significance of the share of capital of foreign investors can be explained by the introduction or strengthening of innovative culture and competent management, as well as by the introduction of products and processes into local subsidiaries that are already known within the parent company. Such findings are in line with assumptions that firms with a higher share of capital held by foreign investors are more innovative both because the inflow of foreign direct investments can provide an external source of knowledge and skills, as well as because foreign investors may actually prefer to invest in firms with stronger capabilities for innovation. Statistical significance of the demand pull variable can be explained by increasing competitiveness, which forces the Croatian companies to involve new innovative elements in their business strategies such as introducing new products or increasing capacity. The statistical significance of the variable 'the international market being most important' can be explained by the more intense competition in foreign markets, which increases the incentives of exportoriented firms to innovate.

To check for multi-collinearity, we also report the variance inflation factor (VIF) in the last column of Table 4. The VIF is defined as $\left(1-R_{i}^{2}\right)^{-1}$ where $R_{i}^{2}$ is the $R^{2}$ obtained from regressing the $i$-th exogenous variable on all other independent variables. Consequently, a high VIF indicates multi-collinearity. However, the VIF values are all below 2 , showing that there is no serious multi-collinearity problem among the independent variables and thus there is no need to compress the variation of the variables by the use of, for example, factor analysis.

\section{Concluding Remarks}

Although innovation tends to be considered an important driver of economic growth, its dynamics seem only partially understood. In this paper we have attempted to analyse some of the main aspects of innovation activities in Croatian enterprises, based on the results of the first Community Innovation Survey for Croatia. Innovation activities still tend to occupy a peripheral role within competitive strategies of most Croatian companies, which limits the resources and competences devoted to their development, and, correspondingly, their economic effects (cf. Račić et al., 2005). However, several factors that facilitate innovation performance can be identified.

We have observed an inverted U-shape relation between size of the firms and their innovation propensity, whereby innovation propensity (i.e. the likelihood of introducing a new product or service) increases with firm size, measured by the number of employees, but then drops in the case of the largest companies that have not undergone restructuring. However, increases in the size of firms are associated with decreasing shares of innovative sales. Larger companies seem to have greater problems in effectively translating innovation into favourable economic outcomes. On the other hand, there is no clear relationship between the level of complexity of products and technologies of specific industries and their innovation performance. That could be related to other firm-level factors that may influence innovation, including product diversification, firm-specific capabilities and the level of competition in a particular industry.

The qualification structure of firms turned out to be insignificant in relation to the share of sales of innovative products, unlike the participation of foreign investors, continuous engagement in R\&D and R\&D cooperation and, to a lesser extent, demand pull factors. All of the variables whose significance has been established (i.e. enterprise size, foreign direct investment, export orientation and the demand pull variable) are fairly interconnected. They can be tackled through a more effective policy framework that should increase competitiveness within industries in order to stimulate the demand for innovation. The focus should be on fostering enterprise growth, attraction of FDI with strong spillover effects, and stimulating the export capability of enterprises. Only in such a context can the positive effects of engagement in $R \& D$ (including $R \& D$ cooperation) be maximised. On the other hand, the insignificance of employee education levels supports the available findings on the insufficient role of knowledge-related factors in building and maintaining competitive advantage. Although the solution to this should primarily be sought within companies themselves - through improved strategies, innovation activities and human resource management practices - a better alignment of the education sector with the needs of the labour market could also be beneficial. 도 


\section{(Endnotes)}

1 Cohen and Klepper (1992) assumed firm specific, $R \& D$ related capabilities to be determinants of $R \& D$ intensity.

2 The results seem to reflect the industry-specific nature of innovation activities (e.g. process and product nature of innovation in food industry and product innovation in machinery industry). See more about the taxonomy of sectors of production/use of innovation in Pavitt (1984).

3 The CIS questionnaire contains also qualitative information whether firms have introduced process innovations or not. We decided, however, not to consider process innovations in the analysis since the questionnaire contains no quantitative measure of effects of process innovations. For an alternative approach, see e.g. Mairesse and Mohnen (2001) who substituted this missing information for process-only innovating firms with the smallest positive value of the share of innovative sales.

4 Problem with innovation output data may come up as a consequence of misperception of innovation within firms, especially in transition countries where the importance of innovation practice has not been embedded in the business practice. Innovation sales, for example, should be accounted separately from the sales of other products, but this is still not common practice.

5 Please note that 'iff' means 'if and only if'.

$6 \quad y_{i}^{*}$ is called a latent variable since it is not directly observable in the dataset. Additionally, $y^{*}$, should not be interpreted as a probability. For more details see Maddala (1986). $y^{*}$ is only introduced in the model to link the observable dichotomous variable 'Innovation yes/no' to the exogenous variables.

7 These include: mining, food, textile, wood, chemicals, plastic, glass, metals, machinery, electrical, vehicle, supply, retail, transport, finance and other services (OECD 1997).

8 For a more thorough discussion on this topic see e.g. Radic (2005)

9 In his seminal work, Schmookler (1962) was the first to introduce the demand situation as a potential determinant of innovations. For an empirical verification see e.g. Geroski and Walters (1995). Industry affiliation turned out to be insignificant and was therefore excluded from the estimations.

10 For more details see Maddala (1986). The Mills ratio accounts for the fact that the truncated expected value of given $\varepsilon>-x^{\prime} \beta$ is not zero. In fact, from equation (1.2) one can see that not taking account of the truncation of $y$ leads to biased estimation results as long as $\sigma$ is not equal to zero.

11 We also included squared numbers of employees. However, we do not find non-linear size effects.

12 We have earlier mentioned the difference between OECD (1997) definitions of innovation activity and innovation propensity. The results presented here thus differ from the results of the overall survey of innovation activities (Račić et al., 2005), with the largest difference in the sample of the large firms. 


\section{References:}

Aitken, B.J. and A.E. Harrison, 1999. Do Domestic Firms Benefit from Direct Foreign Investments? Evidence from Venezuela. American Economic Review 89: 605-618.

Andrijević-Matovac, V. 2003. Croatian National Innovation System: How to create and transfer knowledge and technology? In Transition Countries in the Knowledge Society, edited by J. Švarc, J. Lažnjak, Ž. Šporer, and D. Polšek, 199-217. The Institute of Social Sciences Ivo Pilar, Zagreb.

Aralica, Z. and Bačić, K. 2005. Evaluation of Croatian innovation capability. In Croatian Accession to the European Union, Facing the Challenges of Negotiations, edited by K. Ott, 129-159. The Institute of Public Finance, Zagreb.

Arrow, K. J. 1962. The economic implications of learning by doing. Review of Economic Studies 29: 155-173.

Arvanitis, S. 1997. The Impact of Firm Size on Innovative Activity - An Empirical

Analysis Based on Swiss Firm Data. Small Business Economics 9: 473 - 490.

Baldwin, J. Hanel, P. and Sabourin, D. 2000. Determinants of Innovative Activity in Canadian Manufacturing Firms:The Role of Intellectual Property Rights. Ottawa, Micro-Economic Analysis Division Statistics Canada. http://www.statcan. ca/english/research/11F0019MIE/11F0019MIE2000122. pdf. (accessed March 15, 2007).

Baumol, J.W. 2004. Entrepreneurial Enterprises, Large Established Firms and Other Components of the Free-Market Growth Machine. Small Business Economics, 23 (1): 9-21.

Boia, M. J. Conceição, P. and Santos, R. 2003. Determinants of Innovation in Portugal: Designing, Implementing and Analyzing Evidence from the Third Community Innovation Survey. Instituto Superior Técnico, Lisbon.

Božić, Lj. Radas, S. 2005. The Effects of Innovation Activities in SME's in the Republic of Croatia. Privredna kretanja i ekonomska politika 15 (103): 30-50.

Caird, S. 1994. How important is the innovator for the commercial success of innovative products in SMEs. Technovation 14 (2): 71-83.

CEU 2000. Presidency conclusions: Lisbon European Council 2000. Bruxelles, Council of European Union. http://ue.eu.int/ueDocs/cms_Data/docs/pressData/en/ ec/00100-r1.en0.htm. (accessed May 10, 2007)
Cohen, W. 2005. Empirical Studies of Innovative Activity. In Economics of Innovation and Technological Change Handbook, edited by P. Stoneman, 182-264. Oxford: Blackwell Publishers Ltd.

Cohen, W. M., Nelson, R. R. and Walsh, J. P. 2000. Protecting their Intellectual Assets: Appropriability Conditions and Why U.S. Manufacturing Firms Patent (or Not). NBER Working Paper 7552, MS: Cambridge.

Cohen W. M. Klepper S 1992. The anatomy ofindustry R\&D intensity distributions. American Economic Review 82: 777-799.

Cohen, W. and Levinthal, D. 1989. Innovation and learning: The two faces of R\&D. Economic Journal 99: 569-596.

Crépon, B., Duguet, E. and Mairesse, J. 1998. Research and Development, Innovation and Productivity: An Econometric Analysis at the Firm Level. Economics of Innovation and New Technology 7: 115-158.

Crespi, M. 2004. Notes on the Determinants of Innovation: A Multi-perspective Analysis. Rome, FEEM Working Paper No. 42/04. http://papers.ssrn.com/sol3/papers. cfm?abstract_id=524503 (accessed June 13, 2007).

Damijan, et al. 2003. Technology Transfer through FDI in Top-10Transition Countries: How Important are Direct Effects, Horizontal and Vertical Spillovers? Ml: Ann Arbor, William Davidson Institute working paper, no.549. http://eres.bus.umich. edu/docs/workpap-dav/wp549.pdf (accessed May 10, 2006).

Dosi. G. 1988. Sources, Procedures, and Microeconomic Effects of Innovation. Journal of Economic Literature 26: 1120-1171.

Geroski, P. A. and Walters, C. F. 1995. Innovative Activities over the Business Cycle. Economic Journal 105: 916-928.

Girma, S., Greenaway, D. and Wakelin, K. 2001. Who Benefits from Foreign Direct Investment in the UK? Scottish Journal of Political Economy 48: 119-133.

Griffith, R., Huergo, E., Mairesse, J., Peters, B. 2006. Innovation and Productivity Across four European Countries. Oxford Review of Economic Policy 22, 4: 483-498.

Griliches, Z. 1990. Patent Statistics as Economic Indicators: A Survey. Journal of Economic Literature 28: 16611707.

Hausman, A., 2005. Innovativeness among small businesses: Theory and propositions for future research. Industrial Marketing Management 34 (8): 773-782. 
Hujer, R. and Radić, D. 2003. Evaluating the Impacts of Subsidies on Innovation Activities in Germany. Frankfurt Discussion Paper, Faculty of Economics and Business Administration Johann Wolfgang Goethe-University. http:// much-magic.wiwi.unifrankfurt.de/Professoren/hujer/papers/rd_eva.pdf (accessed February 14, 2007).

Jaklič, A., Rojec M. and Damijan, J. 2006. Innovation Cooperation and Innovation Activity of Slovenian Enterprises. Paper presented at 32th Annual Conference of European International Business Association (EIBA): Regional and National Drivers of Business Location and Competitiveness, Fribourg, November.

Kickul, J. and Gundry, L. 2002. Prospecting for strategic advantage: the proactive entrepreneurial personality and small firm innovation. Journal of Small Business Management, 40 (2): 85-97.

Kuhlmann, S. 2001. Governance of Innovation Policy in Europe - Three Scenarios. In Innovation Policy in Europe and the US: New Policies in New Institutions, Research Policy - Special Issue 30 6: 953-976.

Kurik, S. et al. 2002. Innovation in Estonian Enterprises 1998-2000. Estonian Institute for Futures Studies, Talinn.

Leiponen, A., 2005. Skill and innovation. International Journal of Industrial Organization 23: 303-323.

Lipparini, A. and Sobrero, M., 1994. The glue and the pieces: Entrepreneurship and innovation in small-firm networks. Journal of Business Venturing, 9 (2): 125-40.

Lööf, H. Heshmati, A. 2006. On the relationship between innovation and performance: A sensitivity analysis. Economics of Innovation and New Technology 15: 317-344.

Lundwall, B.Ä. 1992. National system of innovations: Towards theory of innovation and interactive learning. Printer Publisher, London.

Maddala, G. S. 1986. Limited-Dependent and Qualitative Variables in Econometrics. Cambridge University Press, Cambridge.

Mairesse, J. and Mohnen, P. 2001. To Be or Not To Be Innovative: An Exercise in Measurement. Cambridge, MS: National Bureau of Economic Research (NBER), Working Papers 8644. http://edocs.ub.unimaas.nl/loader/file. asp?id=243 (accessed September 9, 2007)

Mohnen, P. and Dagenais, M. 2000. Towards an Innovation Intensity Index: The Case of CIS 1 in Denmark and Ireland. Montreal, CIRANO. http://www.cirano.qc.ca/pdf/ publication/2000s-20.pdf (accessed January 22, 2007)
Mowery, D. C. and Rosenberg, N. 1989. Technology and the Pursuit of Economic Growth. Cambridge University Press, Cambridge.

Narula, R. 2003. Understanding the growth of international R\&D alliances. In Multinational

Enterprises, Innovative Strategies and Systems of Innovation, edited by J. Cantwell and J. Molero, 129-152. Edward Elgar, Cheltenham.

NCC 2006. Croatia's Competitiveness Challenge: Annual Report on Croatia Competitiveness 2006. National Competitiveness Council, Zagreb.

OECD 1997. The Measurement of Scientific and Technological Activities: Proposed Guidelines for Collecting and Interpreting Technological Innovation Data - Oslo Manual $2^{\text {nd }}$ edition. OECD, Paris.

Patel, P. and Pavitt, K. 2005. Patterns of Technological Activity: their Measurement and Interpretation. In Economics of Innovation and Technological Change Handbook, edited by P. Stoneman, 182-264. Oxford Blackwell Publishers Ltd, Oxford.

Pavitt, K. 1984. Patterns of Technical Change: Towards Taxonomy and a Theory. Research Policy 13(6): 343-73.

Pavitt, K. 1986. Technology, Innovation and Strategic Management. In: Strategic Management Research: A European Perspective, edited by: J. Mc Gee and H. Tomas, 171190. John Wiley \& Sons, New York.

Powell, W.W., Grodal, S. 2005. Networks of Innovators. In The Oxford Handbook of Innovation, edited by J. Fegerberg, D.C. Mowery and R.R. Nelson, 56-85. Oxford University Press, Oxford.

Račić, D. et al. 2005. Innovation in Croatian Enterprises. The Institute of Economics, Zagreb.

Račić, D. and Cvijanović, V. 2005. Privatization, Institution Building and Market Development: The Case of Croatia. In Path-depedent development in the Western Balkans: the impact of privatization, edited by S. Kusic, 43-77. Peter Lang, Frankfurt am Main.

Radić, D. 2005. Econometric Analysis of Innovation Activities. Peter Lang, Frankfurt am Main.

Radošević, S. 2004. A Two-tier or Multi-tier Europe? Assessing the Innovation Capacities of Central and Eastern European Countries in the Enlarged EU. Journal of Common Market Studies 42(3): 641-666.

Radosevic, S. 1999. Patterns of Innovative Activities in 
Countries of Central and Eastern Europe: An Analysis Based on Comparison of Innovation Surveys. Sussex, SPRU Electronic Working Paper No 35. http://www.sussex.ac.uk/ Units/spru/publications/imprint/sewps/sewp35/sewp35. pdf (accessed February 6, 2007).

Raymond, W. P. et al. 2006. Persistence of innovation in Dutch manufacturing: Is it spurious? Munich, CESifo Working Paper Series No 1681. http://ssrn.com/abstract=894203 (accessed April 14, 2007)

Rosenberg, N. 1982. Inside the Black Box: Technology and Economics. Cambridge University Press, Cambridge.

Sanna-Randaccio, F., R. Veugelers 2003. Global innovation strategies of MNEs: Implications for host economies. In Multinational Enterprises, Innovative Strategies and Systems of Innovation, edited by J. Cantwell and J. Molero, 14-46. Edward Elgar, Cheltenham.

Schmookler, J. 1962. Economic Sources of Inventive Activity. Journal of Economic History XXII (1): 1-20.

Szabo, A. 2002. Internationalisation of SMEs: The UNECE Approach. Geneva, UNECE. http://www.unece.org/indust/sme/internat.htm (accessed August 12, 2007)

Švarc, J. 2006. Socio-political factors and the failure of innovation policy in Croatia as a country in transition. Research Policy 35 (1): 144-159.

Teece, D. J. 1977. Technology Transfer by Multinational Firms: The Resource Cost of Transferring Technological Know-how. Economic Journal 87 (346): 242-261.

Teece, D. J. 1986. Profiting from Technological Innovation. Research Policy 15 (6): 285-306.

Vinding, A. L. 2002. Absorptive capacity and innovative performance: A human capital approach. In Interorganisational Diffusion and Transformation of Knowledge in the Process of Product Innovation. Ph.D. dissertation, Institut for Erhvervsstudier, Ålborg Universitet. 